\title{
TRADISI PANTAUAN BUNTING DALAM PERKAWINAN MASYARAKAT DESA SUKARAMI PAGARALAM
}

\author{
Putri Indah Sari ${ }^{1}$, Moh. Syawaludin ${ }^{2}$, Sholeh Khudin ${ }^{3}$ \\ ${ }^{123}$ Program Studi Sejarah Peradaban Islam Fakultas Adab Dan Humaniora \\ UIN Raden Fatah Palembang \\ Gmail: spiadab uin@radenfatah.ac.id
}

\begin{abstract}
Abstrak
Penelitian ini berjudul Tradisi Pantauan Bunting Pada Mssyarakat Desa Sukarami Pagaralam, dari pokok penelitian ini adalah 1.Bagaimana prosesi pelaksanaan tradisi Pantauan Bunting dalam perkawinan masyarakat desa Sukarami.2.Bagaimana perkembangan pelaksanaan tradisi Pantauan Bunting dalam perkawinan pada masa sekarang. Tujuan Penelitian Ini adalah .Untuk mengetahui prosesi pelaksanaan tradisipantauan bunting dalam perkawinan pada masyarakat desa Sukarami .Untuk mengetahui perubahan dan perkembangan tradisi pantauan bunting dalam perkawinan masyarakat desa Sukarami. Dari Hasil Penelitian Yang di Lakukan, maka peneliti menemukan beberapa hal baru bahwa Tradisi Pantauan Bunting merupakan suatu tradisi yang masih dilaksanakan masyarakat Pasemah, khususnya masyarakat desa Sukarami dalam rangkaian kegiatan upacara perkawinan yang berbentuk undangan atau ajakan makan dari masyarakat setempat terhadap pasangan penganten yang baru menikah. Tradisi Pantauan Bunting ini dilaksanakan dengan tujuan untung Muji Jurai atau menghormati keturunan, sebagai rasa syukur dan hormat terhadap keturunan mereka karena sudah ada yang menikah, atau bias juga dikatakan sebagai hadiah dari masyarakat terhadap penganten.
\end{abstract}

Kata Kunci: Pantauan Bunting, Tradisi

\begin{abstract}
This research is entitled The Tradition of Monitoring Bunting in the Sukarami Village Community of Pagaralam, from the main point of this research: 1. How is the procession of the implementation of the Pantauan Bunting tradition in the marriage of the Sukarami village community. The purpose of this study was to find out the procession of the implementation of the pregnant monitoring tradition in marriage in the Sukarami village community. To find out the changes and developments in the marriage monitoring tradition of the Sukarami village community. From the results of the research carried out, the researchers found several new things that the Bunting Monitoring Tradition is a tradition that is still carried out by the Pasemah community, especially the Sukarami village community in a series of wedding ceremony activities in the form of invitations or invitations to eat from the local community for newly married couples. . This Bunting Monitoring tradition is carried out with the aim of profiting Muji Jurai or respecting descendants, as gratitude and respect for their descendants because someone is already married, or it can also be said as a gift from the community to the bride.
\end{abstract}

Keywords: Pregnancy Monitoring, Tradition 


\section{A. PENDAHULUAN}

Masyarakat Indonesia adalah masyarakat majemuk yang memiliki bermacam-macam kebudayaan dan adat-istiadat yang hidup dalam kesatuan sosial.Dengan kemajemukan itulah yang menimbulkan banyak perbedaan-perbedaan suku, ras, tingkat sosial, agama, dan kebudayaan (kebiasaan). Keanekaragaman ini yang mempercaya khasanah budaya masyarakat Indonesia.Adat istiadat tradisi ini masih berlaku dalam lingkungan masing-masing etnis.Kenyataan menunjukan bahwa kebudayaan masyarakat Indonesia telah tumbuh dan berkembang sejak ribuan tahun yang lalu.Hal ini merupakan warisan para leluhur bangsa Indonesia yang masih dilaksanakan oleh masyarakat Indonesia dan selalu mewarnai kehidupan masyarakat dimasa sekarang ${ }^{1}$.

Adat perkawinan di Indonesia banyak sekali macam ragamnya.Setiap suku bangsa memiliki adat perkawinan masing-masing. Diantaranya adat perkawinan itu ada yang hampir serupa terutama pada suku-suku yang berdekatan, tetapi ada pula yang sama sekali suku-suku yang berlainan. Pada dasarnya, adat perkawinan suku bangsa Indonesia bertolak dari anggota masyarakat bahwa perkawinan adalah suatu ikatan yang sakral dan merupakan salah satu yang tidak bisa dihindari oleh manusia.Pernikahan bukan sekedar ikatan antara seorang laki-laki dan seorang perempuan tetapi juga merupakan proses penyatuan dua keluarga.

Perkawinan merupakan unsur dari kebudayaan tidak hanya sekedar dilakukan secara agama dan hukum positif yang hidup dimasyarakat saja, dalam perkawinan terdapat unsur yang merupakan tradisi adat, ritual upacara secara adat istiadat yang berbeda-beda, keragaman budaya yang hidup di Indonesia merupakan sebuah harta yang patut dijaga dan dilestarikan.

Kota Pagaralam adalah salah satu kota di provinsi Sumatra Selatan, kota ini memiliki luas sekitar 633,66 km dengan jumlah penduduk 126.181 jiwa dan memiliki kepadatan penduduk sekitar 199 jiwa $/ \mathrm{km}$, Kota Pagaralam, sebuah kota yang terletak di kaki gunung Dempo, mempunyai hawa yang sejuk, subur, penghasil kopi, dan sayur mayur yang berlimpah selain terkenal dengan peninggalan budaya megalitiknya yang sangat monumental dan sudah mendunia disebut juga Kota Perjuangan ${ }^{2}$. Di kota Pagaralam ada sebuah desa yang bernama desa Sukarami, Di desa Sukarami Kota Pagaralam, ada sebuah adat atau tradisi yang masih dipegang secara normative terutama dalam tradisi pantauan bunting dalam rangkaian perayaan perkawinan. Kota Pagaralam yang dikenal dengan suku Pasemah dalam melaksanakan perkawinan terdapat beberapa macam sistem perkawinan antara lain:

1. Kawin Tunak yaitu seorang laki-laki menyunting seorang perempuan untuk dinikahi dan dijadikan istri, dan setelah menikah sang istri ikut keluarga laki-laki (suami)

2. Kawin ambik anak yaitu dimana seorang laki-laki atau calon suami, menyunting seorang perempuan untuk dinikahi dan dijadikan istri, dan setelah menikah sang suami (laki-laki) ikut keluarga istri.

3. Kawin rasan tueyaitu jejaka atau calon suami dicarikan calon istri oleh orang tuanya atau sebaliknya seorang gadis atau calon istri dicarikan calon suami oleh orang tuanya untuk dinikahkan, dan setelah menikah calon suami atau calon istri boleh memilih ikut keluarga suami atau keluarga istri.

Dari tiga sistem perkawinan diatas merupakan sistem perkawinan pada masyarakat Pagaralam, khususnya pada masyarakat desa Sukarami.Dan tradisi pantauan bunting tetap dilaksanakan dalam rangkaian perayaan perkawinan tanpa memandang sistem perkawinan yang mana yang dilaksanakan oleh masyarakat.

Mengawali pembicaraan tentang adat pembicaraan bujang-gadis besemah, dirasa perlu di bicarakan dulu pengertian kata bujang dan gadis di kalangan mayarakat besemah.Konsep bujang

\footnotetext{
${ }^{1}$ Musni Umberan, sejarah kebudayaan Kalimantan,(Jakarta: Depdikbud: 1994),hlm 2

${ }^{2}$ Ahmad Bastari Suan,dkk,Tata Cara Adat Perkawinan Sukubangsa Besemah di Sumatra Selatan, (Sumatra Selatan 2010),Hlm.10
} 
di artikan secara umum adalah laki-laki yang sudah baligh (akil-balig) dan belum beristeri.Sedangkan gadis di artikan secara umum perempuan yang sudah baligh dan belum bersuami.

Bila seorang laki-laki telah menjadi bujang dan perempuan telah menjadi gadis, mulailah mereka terlibat atau melibatkan diri dalam pergaulan bujang gadis.Mereka mulai renje (ketertarikan dengan lawan jenis).Kalau bujang mulai ribang (tertarik) dengan gadis, kalau gadis tertarik dengan bujang.Tanda seorang bujang mulai ribang dengan seorang gadis atau sebaliknya, biasa nya ada perasaan ingin selalu bertemu, tetapi keberanian tersebut belum ada.Disinilah peran tokoh ibung (kaum ibu) dalam pergaulan bujang-gadis besemah. Ibung ini menjadi perantara antara bujang gadis, tahap-tahap dalam pergaulan bujang gadis adalah:

\section{Begarih}

Begarih artinya ngobrol-ngobrol tentang hasrat atau pendekatan hati seorang bujang dengan gadis, terutama di saat ada sedekah (kenduri) perkawinan seseorang.

\section{Beghusik atau Betandang}

Bujang berkunjung atau bertamu ke rumah gadis yang biasanya dilakukan pada malam sekitar ba'da isya, ketikah beghusik bapak atau muanay (saudara laki-laki) gadis sedang tidak di rumah.

\section{Nyematung}

Setelah seiring beghusik ke rumah gadis, maka bujang akan nyematung, yaitu membawa ayam, kadang-kadang dibawa pula kelapa untuk dimasak dan dimakan bersama di rumah sang gadis.

\section{Berayak}

Setelah hubungan sang bujang dengan sang gadis makin akrab, sang bujang memberanikan untuk mengajak sang gadis berayak, artinya pergi ke kebun atau hutan untuk mencari sayursayuran atau mengambil punting (kayu bakar) sambaing (tempat air), kadang kala bemban (sejenis buluh yang ruasnya panjang biasanya untuk anyaman).

\section{Begaday}

Bertukar barang antara bujang gadis. Misalnya bujang memberikan itar, sedangkan gadis memberikan kain panjang atau selendang.Biasa kain pemberian suwarian atau linjang (kekasih) tersebut sering diperlihatkan dan dibanggakan di antara kancw (kawan-kawan).

\section{Ninjau}

Bujang pergi ke dusun lain dengan tujuan untuk mencari suwarian atau linjang. Biasanya dusun dituju bujang tersebut sedang ada sedekah atau kenduri.

\section{Maretandang}

Bujang pergi ke dusun lain untuk beberapa hari, biaanya ia menginap di rumah kerabat atau di rumah teman akrab. Selama di dusun tersebut, bujang melakukan aktivitas seperti ndudul (masak dodol), begarih kadang-kadang ikut berayak.

\section{Ngule}

Gadis yang di ajak oleh kerabatnya yang sedekah (kenduri) di dusun lain. Biasanya sang gadis menginap beberapa hari di rumah kerabatnya yang sedang sedekah. Adakalanya, ketika musim ngetam (panen) tiba di suatu dusun, gadis itu dikatakan juga ngule. Biasanya, ketika ada gadis dating, ia sering di hampiri oleh bujang dusun itu.

Pantauan bunting adalah suatu tradisi atau kebiasaan yang dilakukan masyarakat, dan merupakan rangkaian kegiatan dalam perayaan perkawinan yang berbentuk suatu ajakan, atau undangan makan dari setiap kepala keluarga terhadap sepasang pengantin yang baru menikah.Sedangkan tata cara pelaksanaannya sama hal nya dengan yang biasa dilakukan oleh masyarakat di desa-desa lain yang ada di Pagaralam, bahwa sebelum bunting (penganten) 
diundang oleh masyarakat terlebih dahulu pihak keluarga penganten memberi tahu kepada masyarakat dengan mendatangi rumah-rumah dan mengatakan bahwa ada salah satu dari anggota keluarganya akan menikah, tentu saja memberitahu tentang pelaksanaan perkawinan tersebut akan diadakan pada hari apa, tanggal berapa, bulan berapa, sehingga masyarakat mempunyai persiapan untuk melaksanakan tradisi pantauan bunting tersebut. Pemberitahuan ini dalam bahasa Pagaralam adalah besuare.

Penelitian ini lebih difokuskan pada tradisi pantauan bunting dalam perkawinan masyarakat di desa Sukarami.Penelitian ini menarik untuk diteliti karena: pertama, masyarakat di desa Sukarami masih berpegang teguh pada adat-istiadat secara umum dan tradisi pantauan buntingpada khususnya. Kedua, mayoritas penduduk masih melaksanakan tradisi pantauan buntingdalam melaksakan kegiatan perayaan perkawinan. ketiga, menurut pengamat peneliti sementara tradisi ini sangat berpengaruh dan tidak bisa lepas dalam kehidupan masyarakat, dimana apabila ada salah satu warga tidak melaksakan pantauan bunting maka akan menjadi bahan pembicaraan oleh masyarakat disekitarnya. Ke empat, ada perubahan dan perkembangan terhadap busana yang dipakai pengantin dalam melaksakan tradisi pantauan bunting, yaitu dahulu pengantin memakai kebaya dan jas setelah akad nikah, tetapi pada zaman modern (sekarang) boleh memakai baju muslim dan wanita memakai gamis muslim di desa Sukarami Pagaralam. $^{3}$

\section{B. RUMUSAN DAN BATASAN MASALAH}

Dengan melihat latar belakang masalah diatas, maka masalah yang akan penulis angkat pada penelitian ini adalah sebagai berikut:

\section{Rumusan Masalah}

1. Bagaimana prosesi pelaksanaan tradisi Pantauan Bunting dalam perkawinan masyarakat desa Sukarami?

2. Bagaimana perkembangan pelaksanaan tradisi Pantauan Bunting dalam perkawinan pada masa sekarang?

\section{Batasan Masalah}

Batasan masalah merupakan batasan yang akan diteliti, untuk memperjelas dan membatasi ruang lingkup penelitian, dengan tujuan mendapatkan hasil uraian penelitian secara sistematis pembatas yang dimaksud agar penulis dalam penelitian ini tidak menyimpang dan melebar dari permasalahan, maka dalam sebuah penelitian diperlukan adanya pembatasan dan perumusan masalah.

Pada bagian ini merupakan bagian yang memberikan penjelasan tentang pembatasan dan perumusan masalah. Pembatasan ini dimaksud agar penulis tidak terjerumus kedalam banyak data yang ingin ditelti, sehingga cakupannya adalah dalam batasan masalah penelitian yaitu tempat dan waktu yang dijelaskan ${ }^{4}$

\section{KERANGKA TEORI}

Sebagaimana telah diuraikan dalam latar belakang masalah bahwa kebudayaan merupakan hasil karya, rasa dan cipta manusia yang berakar dari kebiasaan-kebiasaan atau tradsi dari nenek moyang yang telah mengakar pada masyarakat.Mengingat betapa banyaknya objek kajian dari kebudayaan yang mencakup segala aktivitas manusia dalam kehidupan bermasyarakat, maka

\footnotetext{
${ }^{3}$ Ahmad Bastari Suan,dkk, Tata Cara Adat Perkawinan Sukubangsa Besemah di Sumatra Selatan, (Sumatra Selatan 2010), Hlm,12-15

${ }^{4}$ Dudung Abdurrahman, Metodelogi Penelitian Sejarah Islam, (Yogyakarta: Ombak, 2001 ), Hlm. 126.
} 
yang menjadi objek kajian dari penelitian dalam skripsi ini adalah tradisi pantauan bunting yang merupakan rangkaian kegiatan dari perayaan perkawinan pada masyarakat Desa Sukaramiyang sudah mengakar dan tetap terpelihara.

Para ahli antropologi seperti: Koentjaraningrat, yang mengemukakan pandangannya tentang kebudayaan. Menurutnya kebudayaan sebagai sistem gagasan merupakan hasil dari kehidupan bersama manusia dan masyarakat dengan segala gagasan diperoleh melalui proses belajar dan telah menjadi milik bersama. Sebagai suatu sistem gagasan maka kebudayaan ideal terdiri dari ide-ide, gagasan, norma-norma, adat-istiadat dan sebagainya yang mengatur dan memberi arah kepada tindakan dan karya manusia. ${ }^{5}$ Sedangkan adat atau tradisi pantauan bunting dalam perkawinan masyarakat desa Sukarami merupakan ide, gagasan, norma, adat-istiadat yang telah mereka laksanakan sejak zaman nenek moyang, yang mengatur dan memberikan arah dari tindakan dan prilaku masyarakat setempat dalam menciptakan dan menghasilkan karyanya untuk diterapkan dalam kehidupan bermasyarakat yang belajar dari pengalaman leluhur mereka sehingga terbentuklah sistem ide, gagasan, norma, dan adat-istiadat yang ideal.

Dari berbagai pandangan dan pemikiran (teori) para ahli diatas dapat disimpulkan bahwa tradisi pantauan bunting dalam perkawinan yang ada dalam masyarakat desa Sukarami tersebut timbul karna adanya kebutuhan-kebutuhan serta terbatas nya pengetahuan manusia dalam berusaha untuk mengatasi masalah yang muncul. Maka kebudayaan sebagai sistem gagasan, ide, norma-norma dan adat-istiadat yang merupakan hasil karya, rasa dan cipta masyarakat setempat berfungsi sebagai ketentuan-ketentuan dasar yang memberi arah tentang tindakan dan prilaku manusia dalam kehidupan sehari-hari yang selalu berhubungan dengan masyarakat.

\section{METODE PENELITIAN}

Penelitian ini merupakan penelitian lapangan. Dan akan menggunakan pendekatan antropologi dan sosisologi. ${ }^{6}$ Dengan menggunakan pendekatan ini penulis dapat mendeskripsikan secara jelas mengenai sosial budaya masyarakat setempat.

1. Lokasi Penelitian

Penelitian ini dilakukan di desa Sukarami Kota Pagaralam.Peneliti mengambil lokasi ini karena tradisi yang ada di desa ini menurut pengamat peneliti, selama ini terdapat suatu tradisi yang unik yaitu tradisi pantauan buntingdalam perkawinan dan sangat menarik untuk diteliti, disamping itu juga lokasi ini belum pernah diteliti dalam suatu penelitian.

2. Jenis dan Sumber data

Jenis data dalam penelitian ini adalah data kualitatif, dengan berdasarkan mutu. Sedangkan sumber data yang di gunakan dalam penelitian ini meliputi:

a. Data Primer, yaitu data yang diperoleh dari lapangan melalui observasi dan wawancara mengenai pelaksanaan tradisi pantauan bunting dalam perkawinan masyarakat desa Sukarami Kota Pagaralam yang sumber dari tokoh adat, tokoh agama, tokoh masyarakat dan perangkat desa setempat.

b. Data Sekunder, yaitu data yang diperoleh melalui dokumen atau buku-buku yang ada kaitannya dengan adat atau tradisi dalam kehidupan masyarakat ${ }^{7}$

3. Teknik Pengumpulan Data

Dalam mengumpulkan data peneliti akan menggunakan beberapa metode antara lain:

${ }^{5}$ Koentjaraningrat, Pengantar Antropologi I, (Jakarta: Renika Cipta: 1996), H. 72

${ }^{6}$ Cholid Narbuko dan Abu Achmadi, Metodelogi Penelitian, (semarang: Universitas Indonesia: 1993), H. 46

${ }^{7}$ Coensuelo G. sevilla. Ed, Pengantar Metode Penelitian, (Jakarta: Universitas Indonesia:1993), H. 160-161. 
a. Metode Observasi

Melalui metode ini peneliti langsung ke lapangan untuk mengumpulkan data dengan mengamati dan mencatat semua fenomena yang ada tentang tradisi pantauan bunting dalam perkawinan masyarakat di desa Sukarami Kota Pagaralam yang ada kaitannya dengan permasalahan yang akan dibahas dalam penelitian ini.

b. Metode Interview (wawancara)

Melalui metode ini peneliti langsung ke lapangan untuk mengumpulkan data dari responden tentang tradisi pantauan bunting dalam perkawinan masyarakat, dengan cara mengajukan pertanyaan-pertanyaan yang telah dipersiapkan, seperti $5 \mathrm{w}+1 \mathrm{~h}$,apa itu tradisi pantauan bunting, siapa saja yang terlibat dalam pelaksanaan tradisi pantauan bunting, kapan tradisi pantauan bunting terjadi, dimana proses pelaksaan tradisi pantauan bunting, kenapa masih dipergunakan oleh masyarakat tradisi pantauan bunting, bagaimana proses pelaksanaan tradisi pantauan bunting, dan kemudian responden memberikan jawaban sesuai dengan pertanyaan.

c. Metode Dokumentasi

Melalui metode ini peneliti mencatat data-data yang didapat, baik melalui buku-buku yang berhubungan dengan adat atau tradisi kebudayaan yang ada.

1. Tahap Awal (persiapan)

Seperti dijelaskan sebelumnya dalam melaksanakan tradisi ini masyarakat telah mempersiapkan terlebih dahulu bahan dan perlengkapan yang diperlukan untuk dimasak seperti peralatan makan (sendok, gelas, piring), tempat untuk menghidangkan makanan, dan bahan-bahan yang akan mereka masak untuk pantauan bunting baik bahan membuat kue ataupun untuk lauk pauknya. Dan biasanya ibu rumah tangga atau anak gadisnya sudah berangsur-angsur memasak kue dalam tiga atau dua hari sebelum dilaksanakannya pantauan bunting sehingga pada waktu pelaksanaan mereka tidak begitu repot lagi dan sudah siap menghidangkan makanannya.

Dalam tahapan ini biasanya perlengkapan dan peralatan makan setiap rumah sudah memiliki dengan demikian tidak terlalu dipersiapkan, mereka hanya menyiapkan bahan yang akan dimasak saja.

2. Tahap kedua (rangkaian) Pelaksanaan dan Tata Cara Tradisi Pantauan Bunting

a. Hari pelaksanaan

Tradisi Pantauan Bunting biasanya dilaksanakan pada hari ketika hendak dilaksanakan akad nikah atau sehari sebelum resepsi (perayaan) pernikahan.Tetapi biasa juga dilaksanakan sesudah resepsi. Hal ini diserahkan pada masyarakat atau kerabat untuk menentukan kapan mereka hendak melaksanakan pantauan bunting dalam ati kata keluarga yang mengadakan persedekahan tidak turut ikut campur dalam menentukan kapan mereka akan mengadakan persedekahan tradisi ini. Mengingat banyaknya kepala keluarga yang akan mantau bunting, maka terkadang mereka mencari kesepakatan dan membagi dalam mengundang bunting misalnya, untuk dari sebelah ilir mereka melaksanakan pantauan bunting sebelum akad nikah atau resepsi dan disebelah ulu sesudah akad nikah atau resepsi pernikahan. Hal ini dilakukan masyarakat agar penganten tidak terlalu capek untuk jalan ke ulu ke ilir (bolak balik) untuk pantauan tersebut. ${ }^{8}$

Tradisi ini sudah menjadi rangkaian kegiatan dalam pelaksanaan upacara pernikahan masyarakat Pagar Alam pada umumnya dan khususnya masyarakat desa sukarami. Sebagaimana yang telah kami jelaskan diatas bahwa sebeelum dilaksanakannya kegiatan

\footnotetext{
${ }^{8}$ Ahmad Romson, Pergeseran Pada Perkawinan Masyarakat Besemah , h. 69-70
} 
ini ada rangkaian kegiatan lain yaitu kegiatan besuare. Adapun jarak kegiatan besuare dengan pantauan bunting ini jaraknya lebih kurang 7-12 hari sebelum persedekahan atau dilangsungkannya pernikahan.Hal ini dilakukan untuk memberikan waktu pada masyarakat agar dalam pelaksanaan tradisi ini, ada persiapan sehingga tidak terlalu memberatkan atau membuat masyarakat menjadi tergesa-gesa dalam mempersiapkannya, misalnya apabila mereka tidak ada bahan untuk dimasak, maka mereka masih mempunyai banyak waktu untuk mempersiapkannya.

b. Waktu Pelaksanaan

Pelaksanaan besuare biasanya dilaksanakan oleh keluarga calon penganten pada pagi atau sore hari, mengingat masyarakat desa sukarami banyak berkebun, maka hanya pada pagi dan sore harilah mereka ada di rumah sedangkan pada siang hari merek pergi ke lading atau ke sawah. Begitu juga dengan pelaksanaan pantauan bunting juga dilaksanakan pada pagi hari dan sore hari, pagi hari sekitar jam 08.00 sampai 11.00 , sedangkan sore hari sekitar jam 16.00 sampai 17.30 dan sekitar ka, 14.00 sampai 13.30 biasanya dilaksanakan acara akad nikah.

c. Tempat Pelaksanaan

Pelaksanaa tradisi pantauan bunting ini dilaksanakan pada rumah-rumah atau di rumah masing-masing penduduk (kepala keluarga) itu sendiri. Di mana pasangan penganten akan naik turun tangga dari rumah satu ke rumah yang lain dan diikuti oleh bujang dan gadis ngantat (pengiring) serta satu atas dua orang dari pihak keluarga penganten.

d. Tata Cara (jalannya) Tradisi Pantauan Bunting

Dalam Perkawinan Ketika akan dimulainya tradisi ini, pihak keluarga yang akan mengadakan pantauan bunting tersebut telah menyajikan makanan dan minuman yang sudah dihidangkan dan siap untuk dimakan. Setelah melihat keadaan sudah siap maka mereka saling memberitahu dengan tetangganya untuk menjemput penganten dan salah satu diantara mereka atau anggota keluarga tersebut pergi menjemput penganten di rumah tempat di mana mereka tersebut tinggal.

Kemudian meminta izin kepada keluarga penganten bahwa mereka ingin mengajak bunting makan kerumah mereka. Pasangan penganten kemudian bersiap-siap keluar dari rumah dengan diikuti oleh bujang gadis ngantat( pengiring) serta satu atau dua orang dari kerabat penganten untuk mendampingi dalam pantauan menuju rumah orang yang memanggil mereka tersebut.Sedangkan masyarakat sudah menunggu kedatangan penganten dan menyambutnya. Pasangan penganten pun mulai pantauan dari rumah satu ke rumah yang lain secara bergilir.

Ketika bunting (pengantin) sudah menaiki rumah, keluarga yang mengundang mereka tersebut menyambut ramah dengan berjabatan tangan dan mempersilahkan masuk dan duduk dengan menghadapi hidangan yang telah tersedia. Kamudian penganten beserta rombongan duduk dengan menghadapi hidangan dan makan, pada saat penganten makan tuan rumah mulai bercerita atau memberitahu bahwa antara mereka dengan keluarga penganten laki-laki atau penganten perempuan masih dek bradek (saudara) dengan memperkenalkan keluarga mereka misalnya, ini nenek, wak, atau bibi dan sebagainya.

Setelah selesai makan dan sedikit ramah tamah bunting (pengantin) kemudian turun dan naik kerumah berikutnya merekapun juga melakukan hal yang sama seperti sebelumnya. Setelah selesai pantauan penganten beserta rombongan kembali kerumah tempat tinggal mereka. ${ }^{9}$

\footnotetext{
${ }^{9}$ Wawancara Pribadi Bapak Supriadi, pada tanggal 12 desember 2020 pukul 10;00
} 
Tanjak: Jurnal Sejarah dan Peradaban Islam, Vol. I No. 2, 2021

\section{E. PERUBAHAN DAN PERKEMBANGAN TRADISI PANTAUAN BUNTING DALAM PERKAWINAN}

\section{Perubahan}

Seperti telah di jelaskan sebelumnya tradisi pantauan bunting yang dilaksanakan masyarakat sebagai wujud dari rasa syukur, hormat dan penghargaan masyarakat terhadap keturunan yang dikenal dengan muji jurai karena masyarakat yang hidup pada saat itu masih sangat kekurangan saudara atau kerabat, sehingga setiap ada yang dating keperkampungan tersebut, mereka anggap kerabat atau saudara bagi mereka.

Namun seiring dengan berjalannya waktu dan adanya perkembangan zaman, mau tidak mau akan terjadi perubahan dari generasi ke generasi berikutnya. Dengan semakin bertambahnya penduduk dan lingkungan perkampungan pun juga semakin meluas, ternyata kebiasaan atau adat-istiadatpun ikut berubah dan disesuaikan dengan keadaan masyarakat sekarang.

Tradisi Pantauan Bunting di masa sekarang, kelihatannya terdapat perubahan dalam tata cara serta alat dan perlengkapan yang dipakai masyarakat untuk menghidangkan makanan tersebut. Sebagaimana tradisi Pantauan Bunting pada zaman dahulu yang mempunyai pengertian mengajak, mengundang penganten dating kerumah, dan pada saat sekarang ini pun pengertiannya masih sama tidak berubah. Dengan adanya perkembangan kebudayaan sehingga banyak perubahan-perubahan yang terjadi begitu juga dengan masyakat basemah (pagaralam), terdapat perubahan dalam melaksanakan adat perkawinan seperti dalam menggunakan pakaian adat daerah lain pada saat perkawinan, misalnya adat Jawa, adat Padang dan sebagainya.

Sedangkan tradisi pantauan bunting, juga terjadi perubahan didalam menyajikan atau menghidangkan makanan, dimana peralatan yang digunakan sesuai dengan keadaan sekarang ini, begitu juga dalam jenis masakan, banyak meniru masakan daerah lain, perubahan ini terjadi disebabkan karena adanya perkembangan dan kemajuan teknologi informasi.

Berdasarkan data yang diperoleh, melalui wawancara dan observasi, dapat diuraikan dan di klarisifikasikan tentang perubahan yang terjadi dalam pelaksanaan, tradisi pantauan bunting, terutama dalam hal penyajian makanan dan peralatan makanan tersebut, adapun perubahan itu antra lain :

a. Perubahan dari segi makanan yang dihidangkan

Pada zaman dahulu, dalam menyajikan makanan untuk pengantin (bunting) antara kerabat yang masih ada hubungan darah (sedaging) dengan kerabat yang sudah jauh ( bukan sedaging) terdapat perbedaan. Perbedaan tersebut apabila masih ada hubungan darah, didalam hidangan terdapat ciri makanan, yaitu makanan yang bernama dodol, dan lauknya adalah daging.Lauk daging adalah sebagai simbol bahwa mereka masih sedaging (hubungan darah). Sedangkan kerabat yang sudah sedikit jauh, didalam hidangan tersebut tersaji makanan apa adanya semampu mereka. Tetapi pada masa sekarang, makanan-makanan tersebut tidak lagi sebagai ciri apakah mereka masih ada hubungan darah, atau tidak karena setiap keluarga yang mengadakan pantauan bunting dalam menyajikan makanan semuanya terdapat daging.

b. Perubahan dari segi peralatan

Didalam melaksanakan tradisi pantauan bunting, masyarakat pada zaman dahulu dalam menggunakan peralatan, masih sangat sederhana, sedangkan pada masa sekarang, sudah banyak perubahan.Peralatan yang digunakan untuk laksanakan pantauan bunting sudah banyak yang menggunakan peralatan yang bagus dan mahal, sesuai dengan kemajuan zaman misalnya peralatan seperti piring, gelas, sendok, dan sebagai digunakan yang bagus berbeda dengan peralatan sehari-hari.

c. Perubahan dari segi tempat menghidangkan makanan

Pada zaman dahulu, hidangan untuk pantauan bunting itu berada diatas lantai dengan menggunakan tikar, dan membuat hidangan makan diatasnya. Sedangkan pada masa 
sekarang, mayoritas masyarakat sudah merubah cara tersebut, dengan menggunakan meja makan, dan hidangan tersebut dihidangkan diatas meja. Namun masiha da juga masyarakat yang masih menggunakancara lama, karena dirumah mereka tidak mempunyai meja makan.

d. Perubahan pada masyarakat itu sendiri

Masyarakat desa Sukarami pada zaman dahulu dalam melaksanakan tradisi pantauan bunting ini, satu desa semua melaksanakan tanpa terkecuali, apabila ada salah satu anggota masyarakat, yang melangsungkan upacara perkawinan, sedangkan pada masa sekarang, ini tidak lagi dilakukan mengingat masyarakat desa Sukarami sekarang semakin bertambah, lingkungan perkampunganpun semakin luas, hal ini tidak memungkinkan lagi untuk mengadakan pantauan bunting. Sehingga pada masa sekarang ini sudah berubah, hanya kerabat tertentu yang masih ada hubungan darah saja yang melaksanakan tradisi ini. ${ }^{10}$

\section{Perkembangan}

Seiring dengan perkembangan zaman dan kemajuan teknologi, kebudayaan dan adat istiadat, yang ada dalam masyarakat juga mengalami perkembangan, begitu juga dengan adat perkawinan pada masyarakat basemah, khususnya masyarakat desa sukarami didalam melaksanakan upacara perkawinan, sudah banyak mengikuti perkembangan zaman, seperti untuk memeriahkan dan mengihibur pengantin dan masyarakat dengan mendatangkan sesuatu bentuk musik yang moderen dengan menyewa Band dan orgen tunggal, juga dalam hal pakian, pengantin sudah banyak yang memakai pakian adat dari daerah lain dan sebagainya, tidak banyak lagi yang masih menggunakan adat lama seperti tari-tarian, atau arak-arakan, seperti zaman dahulu.

Tradisi pantauan bunting, dalam perkawinan masih tetap dilaksanakan dan tidak begitu banyak mengalami perkembangan, hal ini terlihat jelas setelah penulis mengadakan observasi langsung dilapangan pada saat pelaksanaan tradisi ini, itu berarti susuai dengan data yang diberikan responden kepada penulis. Tradisi pantauan bunting ini, dari dahulu sampai sekarang, proses dan tata cara pelaksanaan kegiatanya masih sama. Tidak mengalami perubahan dan perkembangan yanng berarti tetap dilaksanakan masyarakat, hanya pada penyajian dan peralatanya saja yang berubah dan berkembang. Tetapi pada masa sekarang pagaralam seperti pada desa lain, tradisi ini dapat dikatakan sudah mulai mengalami kemunduran. Begitu juga pada masyarakat Sukarami.Hal ini dikarenakan tradisi ini dilaksanakan oleh keluarga dekat saja, tidak lagi seluruh masyarakat, namun tradisi ini masih tetap dilaksanakan seperti biasanya. ${ }^{11}$

\section{F. PERSEPSI (TANGGAPAN) DAN KEAKTIFAN MASYARAKAT DESA SUKARAMI TERHADAP TRADISI PANTAUAN BUNTING DALAM PERKAWINAN}

Untuk mengetahui persepsi, atau tanggapan masyarakat desa sukarami, terdahap tradisi pantauan bunting dalam perkawinan, maka dapat dilihat jawaban responden, yang telah peneliti lakukan yaitu mengenai tanggapan masyarakat terhadap sikap dan keaktifan masyarakat yang pernah menyajikan dan mengikuti serta melaksanakan langsungnya tradisi tersebut. Dari beberapa masyarakat ada yang setuju dan ada yang tidak setuju, yang setuju diadakan tradisi ini memberikan alasan bahwa suatu tradisi atau kebaisaan apabilla dilaksanakan dapat memberikan suatu hasil yang positif dan selama tidak bertentangan dengan norma-norma agama. Sedangkan yang tidak setuju biasanya Menyatakan alasan dengan terpaksa mengadakan tradisi ini karena tuntutan orang tua mereka dan tidak boleh jika tidak melaksanakanya karena itu adalah adat, jika

\footnotetext{
${ }^{10}$ Wawancara Pribadi Ibu Yeti Arisanti, Pada Tanggal 15 Desember 2020 pukul 11:00

${ }^{11}$ Wawancara Pribadi Ibu Rela, Pada Tanggal 16 Desember 2020 Pukul 11:00
} 
tidak dilaksanakan keluarga, mereka akan merasa malu dengan masyarakat dusun setempat dengan alasan menjadi topik pembicaraan masyarakat setempat.

\section{G. MANFAAT ADANYA TRADISI PANTAUAN BUNTING}

Dalam perkawinan masyarkat desa sukarami, masyarakat desa sukarami masih melaksanakan tradisi pantauan bunting dalam perkawinan, tidak terlepas dari kebijaksanaan-kebijaksanaan semenjak dari zaman nenek moyang mereka dahulu, dan tradisi ini dilaksanakan selain untuk menghormati dan melestarikan suatu adat atau kebudayaan. Dalam masyarakat juga dapat memberikan manfaat dan dirasakan positif baik masyarakat maupun kepada pasangan pengantin. Untuk lebih jelasnya mengenai manfaat diadakanya tradisi pantauan bunting ini dapat diuraikan sebagai berikut.

1. Manfaat yang dapat dibagi masyarakat terhadap tradisi pantaun bunting dalam perkawinan antara lain

a. Dengan adanya tradisi pantauan bunting ini, mereka sudah menghormati, melestarikan dan mengembangkan salah satu kebudayaan yang telah diwariskan oleh nenek moyang mereka kepada genereasi selanjutnya.

b. Dengan adanya tradisi ini, dapat membuka jalan untuk lebih mempererat tali kekeluargaan dan tetap menjaga tali silaturahmi diantara sesama masyarakat

2. Manfaat yang didapat oleh pasangan pengantin terhadap adanya tradisi pantauan bunting dalam perkawinan.

a. Dengan adanya tradisi pantauan bunting, dapat memberikan kesempatan, atau peluang terhadap pasangan pengantin untuk mengenal lingkungan dan berbuat baik kepada masyarakat setelah mereka hidup bermasyarakat, terutama apabila ada kegaiatan pantauan bunting dimasa akan datang.

b. Dengan adanya tradisi ini, akan menambah kecintaan bagi pasanngan pengantin terhadap lingkungan masyarakat setempat, terutama keluarga yang masih ada hubungan keluarga.

c. Dengan adanya tradisi ini, dapat membantu pasangan pengantin yang baru menikah mengetahui sanak keluarga mereka, terutama bagi mempelai yang baru memasuki keluarga tersebut

Upacara perkawinan didalam Islam tersebut dengan Walimah, hikmah dari walimah adalah untuk mengumumkan atau memberitahukan kepada masyarakat bahwa telah terjadi suatu hubungan yang sah dan resmi, diantara kedua pasangan tersebut.Pelaksanaan walimah atau upacara perkawinan yang dilangsungkan pada hari yang telah ditentukan, namun tidak dirujuk dengan tegas.Dilingkungan mana saat terjalinya ikatan perkawinan tersebut, jadi dengan demikian perayaan walimah itu sangat penting dalam suatu perkawinan. ${ }^{12}$

Dari berbagai manfaat di atas, dapat penulis pahami dan simpulkan bahwa tradisi pantuan bunting ini, untuk memberikan tahukan kepada masyarakat banyak atau dusun halaman mengenai pasangan pengantin yang baru membentuk rumah tangga tersebut agar mereka dapat hidup bermasyarakat dan menyesuaikan diri pada lingkungan terutama pada saat mereka hendak melangkahkan kaki didalam kehidupan yang baru. Disamping itu untuk melestarikan suatu tradisi pantauan bunting atau adat istiadat yang telah mereka yakini selama ini agar tetap terjaga dan terpelihara.Berikut adalah dokumentasi Tradisi Pantauan Bunting di Desa Sukarami Pagaralam.

\footnotetext{
${ }^{12}$ Wawancara Pribadi, Ibu Len, Pada tanggal 17 Desember 2020 Pukul 10:00
} 


\section{DAFTAR PUSTAKA}

Abdurrahman, Perkawinan Menurut Syariat Islam.Jakarta: Renika Cipta: 1989

Asrin, Budaya Perkawinan Suku Pasemah Di Padang Guci Di Bengkulu 1980. Sumatera Selatan. 2010

Bastari, Suan Ahmad, dkk, Tata Cara Adat Perkawinan Suku bangsa Besemah di Sumatra Selatan. Sumatra Selatan. 2010

Coensuelo G. Sevilla. Ed, Pengantar Metode Penelitian, (Jakarta: Universitas Indonesia:1993

Dudung Abdurrahman, Metodelogi Penelitian Sejarah Islam. Yogyakarta: Ombak. 2001

Hadikusuma, Hilman. Hukum Perkawinan Adat. Bandung: Cita Adhitiyah Bakti.1990

Koentjaraningrat, Pengantar Antropologi I.Jakarta: Renika Cipta: 1996

Narbuko, Cholid dan Abu Achmadi. Metodelogi Penelitian. Semarang: Universitas Indonesia: 1993

Peeters, Jeroen. Kaum Tuo Kaum Mudo Perubahan Religius di Palembang (1821-1924). Jakarta: INIS :1997)

Romson Achmad, Laporan Penelitian Peta Budaya Sumatera Selatan Mengenai Pergeseran Pola Perkawinan Masyarakat Besemah.

Umberan, Musni, Sejarah Kebudayaan Kalimantan, (Jakarta: Depdikbud: 1994)

\section{WAWANCARA}

Wawancara Dengan Bapak Amrun Selaku Tokoh Mayarakat Desa Sukarami Pada Tanggal 14 Agustus Pukul 16.00 WIB

Wawancara Dengan Ibu Yulistiana Selaku Warga Di Desa Sukarami Pada Tanggal 14 Agustus Pukul 14.00 WIB

Wawancara Pribdi Dengan Dindi Selaku Sekretaris Desa Sukarami Pada Tanggal 30 September Pukul 14.00 WIB

Wawancara Pribadi Dengan Bapak M. Pibo Selaku Kaur Umum Desa Sukarami Pada tanggal 20 Agustus Pukul 11.00 WIB

Wawancara Pribadi Dengan Bapak Pigi Selaku Masyarakat Pada Tanggal 1 Desember 2020 Pukul 09.00 WIB

Wawancara Pribadi Dengan Bapak Persan Selaku Masyarakat Desa Sukarami Pada Tanggal 1 Desember Pukul 11.00 WIB

Wawancara Pribdi Dengan Ibu Asmila Selaku Mayarakat Desa Sukarami Pada Tanggal 16 September Pukul 15.00 WIB

Wawancara Pribadi Dengan Bapak Handitarius Selaku Mayarakat Desa Sukarami Pada Tanggal 15 September Pukul 15.00 WIB

Wawancara Pribadi Dengan Bapak Jhon Hari Selaku Tokoh Agama Mayarakat Desa Sukarami Pada Tanggal 16 Agustus Pukul 15.00 WIB

Wawancara Pribadi Dengan Ibu Anis Fitri Selaku Mayarakat Desa Sukarami Pada Tanggal 17 Agustus Pukul 15.00 WIB

Wawancara Pribadi Dengan Bapak Liuslin Selaku Tokoh AdatDesa Sukarami Pada Tanggal 15 September Pukul 14.00 WIB 